\title{
ERRATUM
}

\section{A novel autoregulatory loop between the Gcn2-Atf4 pathway and L-Proline metabolism controls stem cell identity}

C D’Aniello, A Fico, L Casalino, 0 Guardiola, G Di Napoli, F Cermola, D De Cesare, R Tatè, G Cobellis, EJ Patriarca and G Minchiotti Cell Death and Differentiation (2015) 22, 1234; doi:10.1038/cdd.2015.64

Correction to: Cell Death and Differentiation (2015) 22, 1094-1105; doi:10.1038/cdd.2015.24; published online 10 April 2015

Since the publication of this paper the authors have noted an error in title of the paper.
L-Proroline is incorrect. The correct title is shown above and the corrected paper appears in this issue.

The publishers would like to apologize for any inconvenience this may have caused. 